\title{
Doxorubicin treatment modulates chemoresistance and affects the cell cycle in two canine mammary tumour cell lines
}

Michela Levi ${ }^{1 \dagger}$, Roberta Salaroli ${ }^{1 \dagger}$, Federico Parenti ${ }^{1}$, Raffaella De Maria ${ }^{2}$, Augusta Zannoni ${ }^{1}$, Chiara Bernardini ${ }^{1}$, Cecilia Gola ${ }^{2}$, Antonio Brocco ${ }^{1}$, Asia Marangio ${ }^{1}$, Cinzia Benazzi ${ }^{1}$, Luisa Vera Muscatello ${ }^{1}$, Barbara Brunetti ${ }^{1}$, Monica Forni ${ }^{1}$ and Giuseppe Sarli ${ }^{1 *}$ (DD

\begin{abstract}
Background: Doxorubicin (DOX) is widely used in both human and veterinary oncology although the onset of multidrug resistance (MDR) in neoplastic cells often leads to chemotherapy failure. Better understanding of the cellular mechanisms that circumvent chemotherapy efficacy is paramount. The aim of this study was to investigate the response of two canine mammary tumour cell lines, CIPp from a primary tumour and CIPm, from its lymph node metastasis, to exposure to $\mathrm{EC} 50_{(20 \mathrm{~h})} \mathrm{DOX}$ at 12,24 and $48 \mathrm{~h}$ of treatment. We assessed the uptake and subcellular distribution of DOX, the expression and function of P-glycoprotein (P-gp) and Breast Cancer Resistance Protein (BCRP), two important MDR mediators. To better understand this phenomenon the effects of DOX on the cell cycle and Ki67 cell proliferation index and the expression of p53 and telomerase reverse transcriptase (TERT) were also evaluated by immunocytochemistry (ICC).
\end{abstract}

Results: Both cell lines were able to uptake DOX within the nucleus at $3 \mathrm{~h}$ treatment while at $48 \mathrm{~h}$ DOX was absent from the intracellular compartment (assessed by fluorescence microscope) in all the surviving cells. CIPm, originated from the metastatic tumour, were more efficient in extruding P-gp substrates. By ICC and qRT-PCR an overall increase in both P-gp and BCRP were observed at $48 \mathrm{~h}$ of $\mathrm{EC}^{5} \mathrm{O}_{(20 \mathrm{~h})} \mathrm{DOX}$ treatment in both cell lines and were associated with a striking increase in the percentage of p53 and TERT expressing cells by ICC. The cell proliferation fraction was decreased at $48 \mathrm{~h}$ in both cell lines and cell cycle analysis showed a DOX-induced arrest in the S phase for CIPp, while CIPm had an increase in cellular death without arrest. Both cells lines were therefore composed by a fraction of cells sensible to DOX that underwent apoptosis/necrosis.

Conclusions: DOX administration results in interlinked modifications in the cellular population including a substantial effect on the cell cycle, in particular arrest in the S phase for CIPp and the selection of a subpopulation of neoplastic cells bearing MDR phenotype characterized by P-gp and BCRP expression, TERT activation, p53 accumulation and decrease in the proliferating fraction. Important information is given for understanding the dynamic and mechanisms of the onset of drug resistance in a neoplastic cell population.

Keywords: Canine mammary tumour, Cell line, Chemoresistance, Doxorubicin, P-glycoprotein, BCRP, Cell cycle, p53, Telomerases, Proliferation index

\footnotetext{
* Correspondence: giuseppe.sarli@unibo.it

${ }^{+}$Michela Levi and Roberta Salaroli contributed equally to this work.

'Department of Veterinary Medical Sciences, University of Bologna, Ozzano dell'Emilia, Italy

Full list of author information is available at the end of the article
}

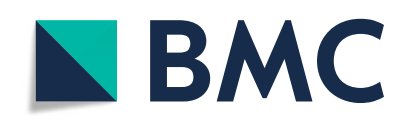

(- The Author(s). 2021 Open Access This article is licensed under a Creative Commons Attribution 4.0 International License, which permits use, sharing, adaptation, distribution and reproduction in any medium or format, as long as you give appropriate credit to the original author(s) and the source, provide a link to the Creative Commons licence, and indicate if changes were made. The images or other third party material in this article are included in the article's Creative Commons licence, unless indicated otherwise in a credit line to the material. If material is not included in the article's Creative Commons licence and your intended use is not permitted by statutory regulation or exceeds the permitted use, you will need to obtain permission directly from the copyright holder. To view a copy of this licence, visit http://creativecommons.org/licenses/by/4.0/. The Creative Commons Public Domain Dedication waiver (http://creativecommons.org/publicdomain/zero/1.0/) applies to the data made available in this article, unless otherwise stated in a credit line to the data. 


\section{Background}

The ability of cancer cells to circumvent the effect of structurally unrelated chemotherapeutic agents is defined as multidrug resistance (MDR) [1-4]. One of the most efficient MDR mechanism is the overexpression of ATP-binding cassette $(\mathrm{ABC})$ transporters by neoplastic cells that can remove substrates by pumping them out of the cell. Modifications of the expression and activity of $A B C$ proteins can lead to an increased pumping out of drugs from the intracellular compartment and therefore to a reduction of the effective concentration of the drug in cancer cells $[5,6]$. In human medicine, Pglycoprotein (P-gp), encoded by the $A B C B 1$ (or MDR-1) gene and the Breast Cancer Resistance Protein (BCRP), encoded by the $A B C G 2$ gene, are two of the many $\mathrm{ABC}$ transporters often associated with the MDR phenotype $[1,7]$. P-gp and BCRP efflux pumps are often co-expressed on the lipid bilayer of cellular plasma membrane but can also be found at the membranes of intracellular organelles where drugs can be segregated [8-11].

One of the most used antineoplastic agents in both human and veterinary medicine is the anthracycline Doxorubicin (DOX). DOX exerts its effects by multiple mechanisms including the production of free radicals, intercalation into DNA strands and inhibition of topoisomerases I and II, causing damage to DNA, resulting in the activation of caspases, which ultimately leads to apoptosis [12, 13]. Nevertheless, DOX is a substrate of both P-gp and BCRP, which can decrease its intracellular concentration therefore limiting antineoplastic action $[14,15]$. Despite extensive clinical utilization, the mechanisms of action of DOX remain under intense debate and further understanding of DOX influence on cell biological events could lead to an improvement in the drug's efficacy [12, 13, 16]. Nowadays, cancer cell lines are successfully used in many studies as an in vitro model to study cancer biology, molecular pathways and test the efficacy of anticancer drugs [17].

Mammary neoplasms are among the most common tumours in dogs and humans [18]. In recent decades, canine mammary tumours (CMTs) have been successfully used as a spontaneous model for breast cancer research and important progress has been observed in veterinary oncology concerning the treatment and knowledge of this disease [19-21].

P-gp and BCRP expression in CMTs has been demonstrated using techniques able to detect their presence at the subcellular level [22-27], however studies investigating the functionality of the pumps with regard to the chemotherapeutic exposure are still incipient in the dog [28-30].

The aims of the present study were: (1) to investigate the MDR mechanism associated with DOX treatment on two CMTs cell lines, comparing the expression of P-gp, BCRP, tumour protein p53 (p53), the catalytic subunit of telomerase, telomerase reverse transcriptase (TERT) and the proliferation index Ki67 between standard condition and exposure to DOX treatment, and (2) to establish a repeatable in vitro model that allows to evaluate the in vivo chemotherapeutic drugs effects.

\section{Results \\ Cell viability and Doxorubicin hydrochloride treatment}

Population doubling times (DT) were very similar in the two cell lines: $23 \mathrm{~h}$ and $17 \mathrm{~min}$ and $20 \mathrm{~h}$ and $29 \mathrm{~min}$ in CIPp and CIPm, respectively. The effect of DOX treatment on CIPp and CIPm viability was evaluated using the MTT assay. The cell lines had very similar sensitivity to DOX. The EC50 values at $20 \mathrm{~h}\left[\mathrm{EC}^{2} 0_{(20 \mathrm{~h})}\right]$ were $12.08 \mu \mathrm{M}$ and $9.431 \mu \mathrm{M}$ for CIPp and CIPm, respectively. The cell viability values, compared to the various concentrations of chemotherapy treatment, are shown in Fig. 1.

\section{Doxorubicin-associated fluorescence evaluation}

By fluorescence microscopy we observed the blue fluorescence of Hoecst33342 in all nuclei of both cell lines, as well as a bright red fluorescence of DOX in the treated cells. In both CIPp and CIPm, after $3 \mathrm{~h}$ of treatment, almost all cells have internalized DOX and are therefore intensely colored red as shown in Figs. 2 and 3, respectively. The superimposition of the images highlights how the drug concentrates in the nucleus (Figs. $2 \mathrm{f}$ and $3 \mathrm{f}$ ). At $48 \mathrm{~h}$, all these surviving cells were unstained because they have extruded DOX (Figs. 2i and 3i).

\section{Cell cycle analysis by flow cytometry}

We investigated the effect of DOX EC50 $(20 \mathrm{~h})$ at 3, 6, 12 and $20 \mathrm{~h}$ on CIPp and CIPm distribution in the cell cycle phases.

CIPp, treated with $\mathrm{EC} 0_{(20 \mathrm{~h})} \mathrm{DOX}$ showed a gradual increase of cells in the S (DNA synthesis) phase compared to the CTR (Fig. 4 and Additional file 1). Increase in $\mathrm{S}$ phase was associated with a progressive decrease of cells in G2/M (mitosis) phase and, at $20 \mathrm{~h}$, there were no cells in G2/M (Fig. 4). The cell cycle underwent therefore an arrest at the $\mathrm{S}$ phase because of DOX treatment. Besides, the hypodiploid sub G0/G1-peak constantly increased reaching $21.76 \% \pm 5.42 \%$ at $20 \mathrm{~h}$ in treated CIPp compared to $5.92 \% \pm 2.61 \%$ in CTR cells (Fig. 4). SubG0/G1 peak was composed by apoptotic cells and by cells that had already lost their DNA by shedding apoptotic bodies, cellular fragments containing pieces of chromatin, broken nuclei, chromosomes and cellular debris [31].

CIPm did not show any severe increase in the $\mathrm{S}$ phase at any time point compared to the untreated controls. However, similarly to CIPp, also CIPm as well presented a gradual increase of the hypodiploid peak in DOX 


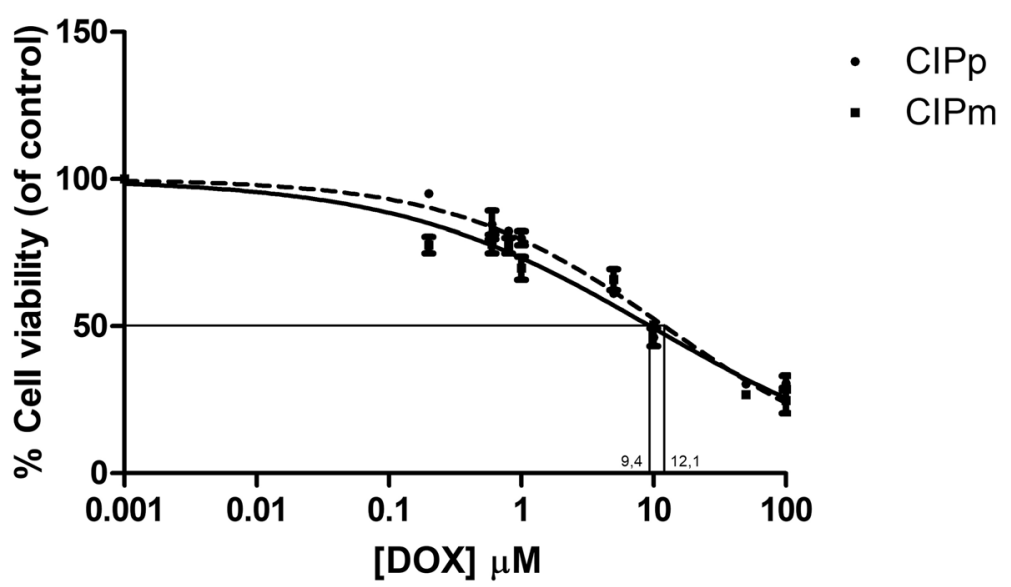

Fig. 1 Effect of DOX on CIPp and CIPm cell viability. DOX impairs cell viability of canine mammary carcinoma cell lines, CIPp (dotted line) and CIPm (continuous line). Cells were treated with increasing concentrations of DOX for $20 \mathrm{~h}$. The values for $\mathrm{EC5}(2 \mathrm{~h})$ were normalized to the control cell lines (untreated) evaluated in the same culturing conditions. Dose-response curves represent mean \pm s.e.m. from three independent experiments, each performed in quadruplicate. $\mathrm{EC50}_{(20 \mathrm{~h})}$ values were calculated using nonlinear regression curve by Prism 7 software (GraphPad San Diego, CA, USA)

treated cells compared to CTR ones $(18.63 \% \pm 5.96 \%$ vs $3.52 \pm 1.68 \%$ ) (Fig. 4 and Additional file 2).

\section{$P$-gp and $B C R P$ gene expression after treatments with Doxorubicin}

CIPp and CIPm were treated with the EC50 (20h) dose of DOX and the $P-g p$ and $B C R P$ gene expression profiles were measured by quantitative Real Time PCR (qRT$\mathrm{PCR})$ at different treatment times $(3,6,12,20,48 \mathrm{~h})$.
$B C R P$ and $P$ - $g p$ were detectable in all samples. A significant increase of both $P$ - $g p$ and $B C R P$ mRNA expression level is evident at $48 \mathrm{~h}$ treatment time point for both CIPp ( $p=0.0009$ and $p=0.0132$, respectively) and CIPm $(p=0.0013$ and $p=0.0209$, respectively) vs controls (Fig. 5). In addition, in CIPp at $12 \mathrm{~h} \mathrm{BCRP}$ expression was significantly higher in the DOX treated and at $3 \mathrm{~h} P$ $g p$ expression of CIPm was significantly higher in the DOX treated cells vs controls.

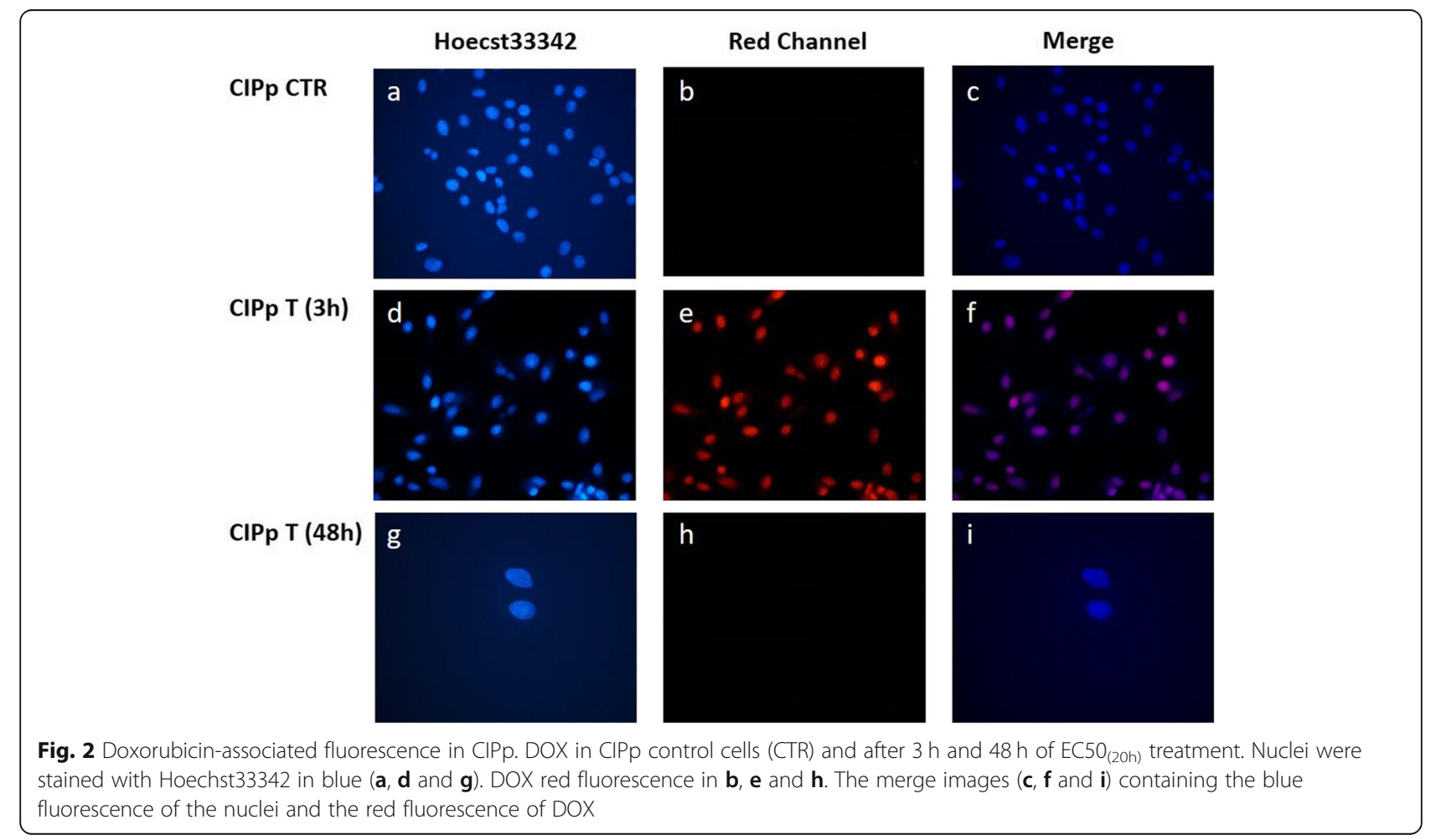




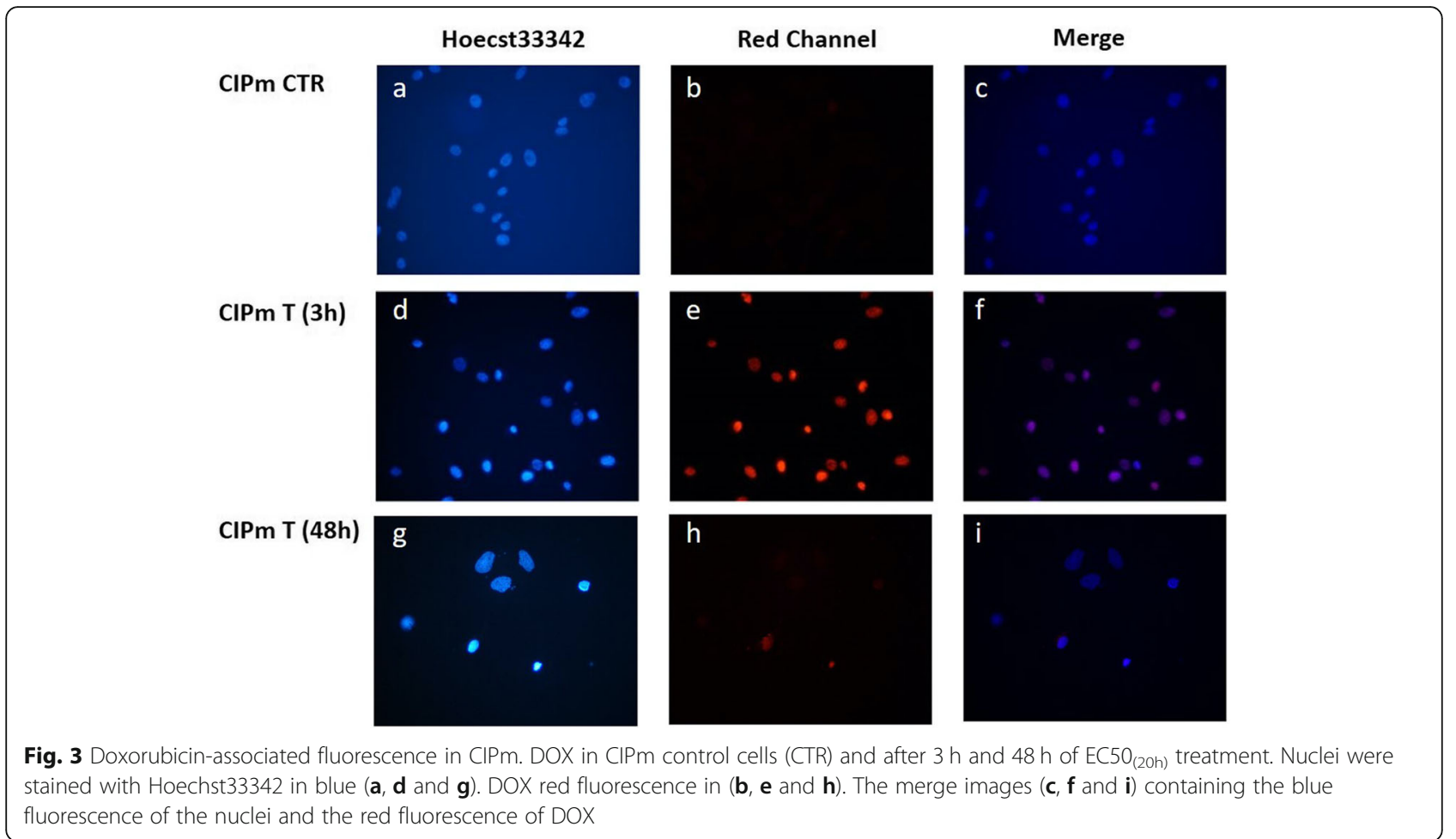

\section{Antibodies validation by Western Blotting}

Western Blot analysis was performed to investigate anti-P-gp (clone C494) and anti-BCRP (clone BXP21) antibodies specificity for dog antigens. Dog liver tissue expressed a single band specific for P-gp and $\mathrm{BCRP}$ at the expected molecular weight of $140 \mathrm{kDa}$ and $70 \mathrm{kDa}$, respectively (see Additional file 3). Antip53, -TERT and -ki67 (Mib1) antibodies specificity for dog tissues had been assessed in previous studies [32-35].
Immunocytochemistry on chamber slides treated with Doxorubicin hydrochloride versus untreated

P-gp, BCRP, p53, TERT expression and the Ki67 proliferation index were evaluated in CIPp and CIPm by immunocytochemistry (ICC) at 12, 24, $48 \mathrm{~h}$ of treatment with the EC50 $(20 \mathrm{~h})$ dose of DOX and compared to the corresponding control cultures. Extremely high density of cells was present at $48 \mathrm{~h}$ culture for the untreated culture; for the $48 \mathrm{~h}$ treatment group, in which cells were less numerous due to the longer treatment exposure, all cells present in

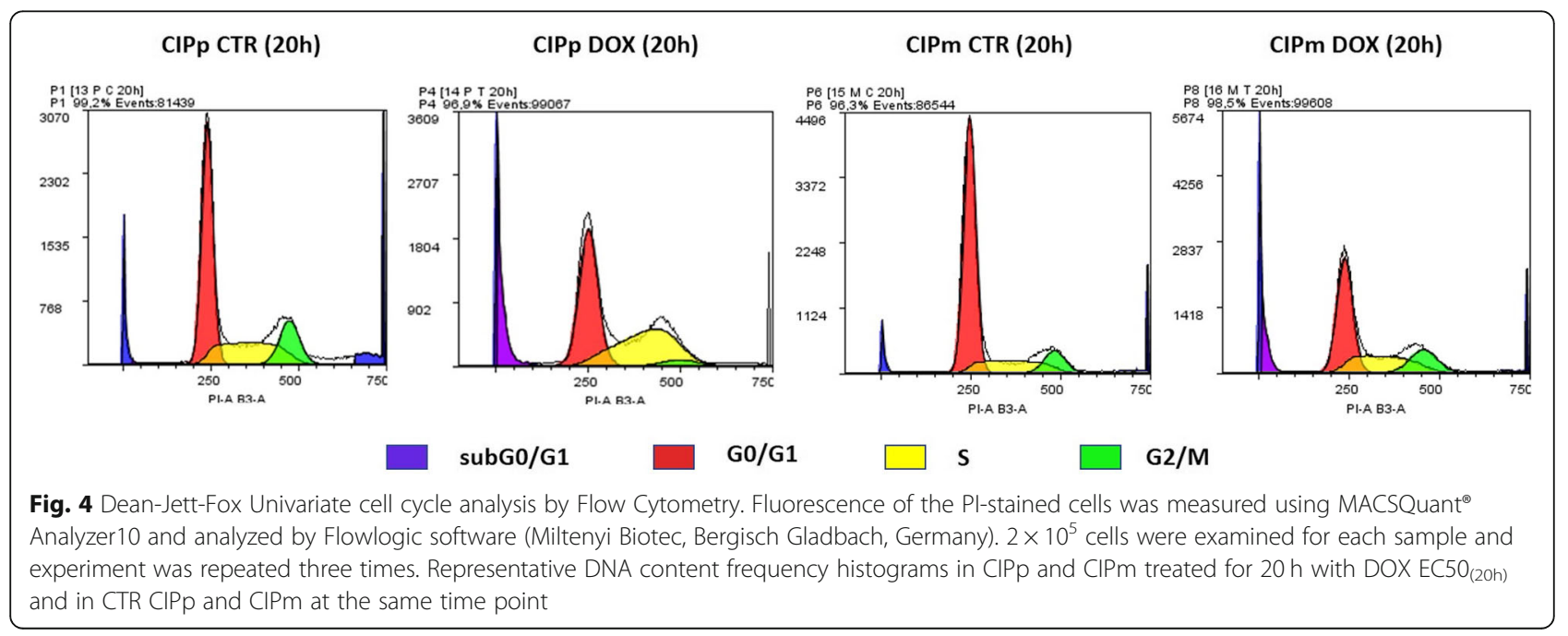




\section{CIPp P-gp}

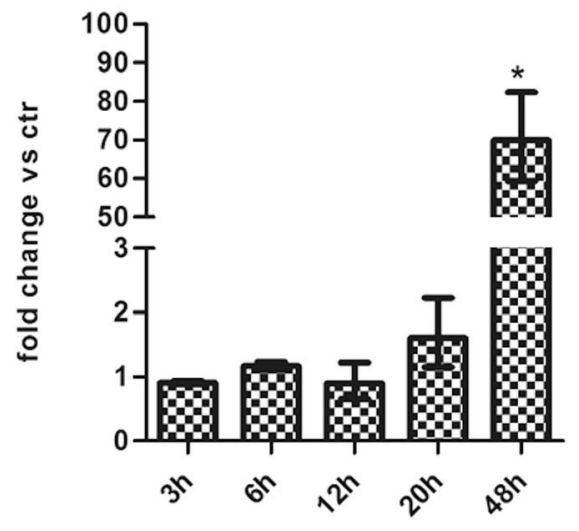

CIPp BCRP

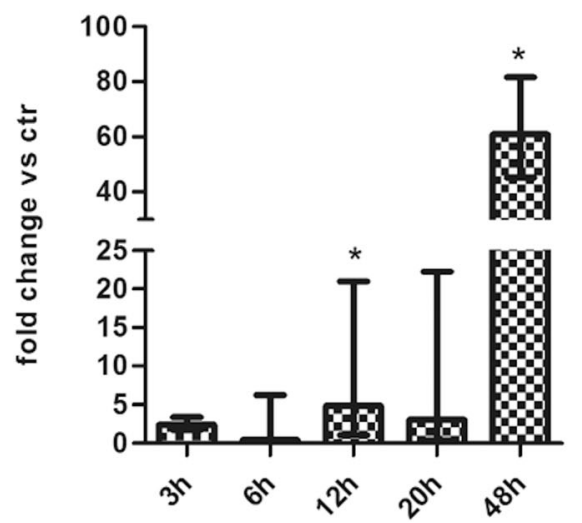

CIPm P-gp

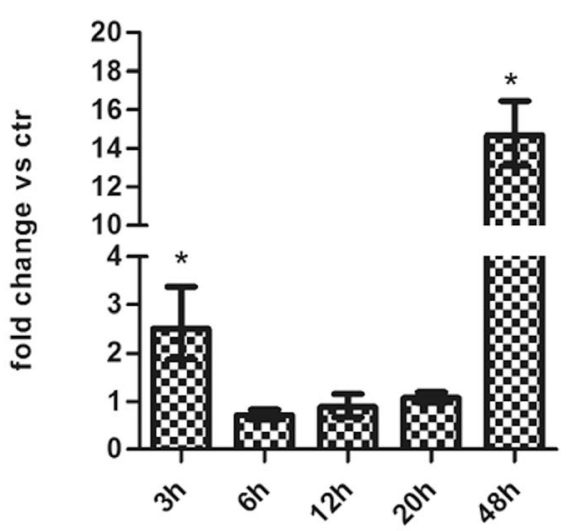

CIPm BCRP

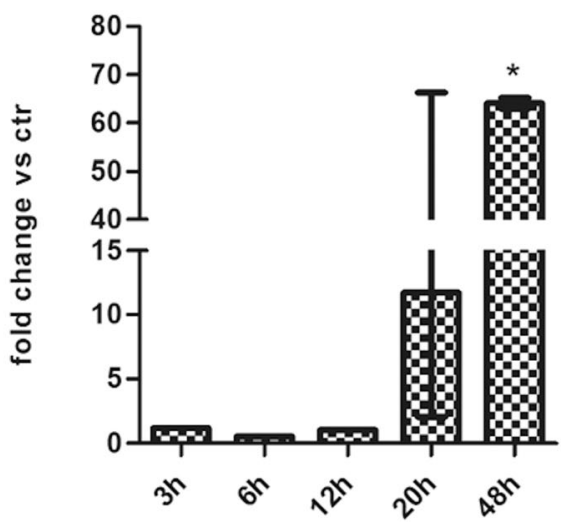

Fig. 5 P-gp and BCRP gene expression in CIPp and CIPm treated with DOX EC50 (20h). Gene expression is calculated with the formula of $2^{-\Delta \Delta C t}$ and shows the fold of change of treated cells vs their relative controls. The bars represent the minimum and maximum expression range of the genes. Asterisk indicates statistically significant differences $(p<0.05)$ calculated with the Student's $t$ test (comparing treated vs ctr at the same time points)

the chamber were examined. ICC results and statistical comparisons are reported in Additional file 4.

Positive staining for P-gp and BCRP was localized at the cell membrane segments, frequently on cytoplasmic vacuoles membranes and less intensely as dispersed granular staining in the cytoplasm (Fig. 6). The percentage of P-gp positive cells were increased at all time points in CIPp with a statistically significant increase at 24 and $48 \mathrm{~h}$ of treatment $(p<0.0001)$. CIPm showed a significantly increased percentage of P-gp positive cells at $48 \mathrm{~h}$ $(p<0.0001)$ and a mild increase at $24 \mathrm{~h}$ treatment. A significant increase in the percentage of BCRP positive cells was seen at all treatment time points for CIPp $(p<0.0001$ at 12 and $24 \mathrm{~h} ; p=0.0151$ at $48 \mathrm{~h})$ and at $24 \mathrm{~h}$ and $48 \mathrm{~h}$ treatment for $\operatorname{CIPm}(p=0.0103$ and $p=0.0413$, respectively) compared to the controls. The treatment with DOX was overall associated with an increase in the percentage of P-gp and BCRP positive cells in the culture by ICC (Fig. 6b and d). The fraction of cells replicating in the populations was evaluated by the Ki67 proliferation antigen as specific nuclear staining in Ki67positive cells (Fig. 6e and f). At $12 \mathrm{~h}$ both cell lines revealed a significantly higher proliferative activity in the DOX treated cultures compared to untreated controls. At $24 \mathrm{~h}$ CIPm showed a mild decrease of the proliferation index, while CIPp proliferation index was significantly increased compared to the respective untreated controls $(p=0.0034)$. At $48 \mathrm{~h}$ of treatment a decrease in the cellular proliferative fraction was present for both cell lines, but statistically significative only for CIPp $(p=0.0118)$.

P53-positive cell showed specific nuclear staining, while cellular TERT-positivity was represented by nuclear and/or granular cytoplasmic staining (Fig. 6g-j).

A striking significant increase was observed for both p53 and TERT expression, compared to controls at each time points $(p<0.0001$ at each time point) except for CIPm at $48 \mathrm{~h}$ treatment when a higher percentage of TERT positive cells was detected in untreated cells. 


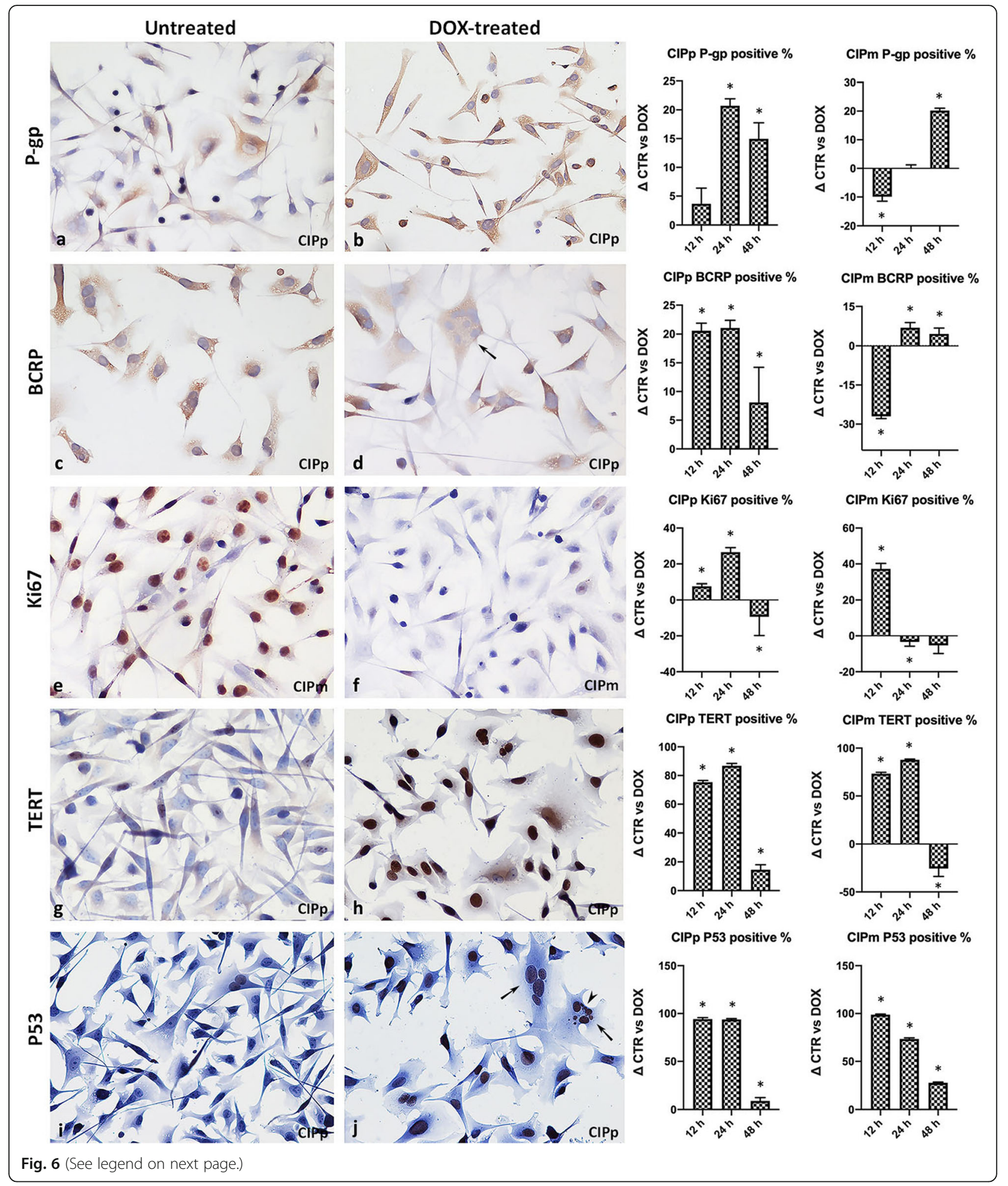


(See figure on previous page.)

Fig. 6 Immunocytochemistry on chamber slides treated with Doxorubicin. Untreated $(\mathbf{a}, \mathbf{c}, \mathbf{e}, \mathbf{g}, \mathbf{i})$ and DOX-treated $(\mathbf{b}, \mathbf{d}, \mathbf{f}, \mathbf{h}, \mathbf{j}) C I P p$ and $C I P m$ ICC with graphs representing the \% differences $(\Delta)$ in positivity between the controls and the DOX-treated cells for each antibody. Cell percentages were averaged over triplicate samples, and the data are expressed as the mean \pm SD, asterisk represent a significant difference ( $p<$ 0.05 ) between controls and treated cells by two-tail Fisher exact test. ICC at $24 \mathrm{~h}$ treatment for P-gp in untreated (a) and DOX-treated (b) CIPp cell line. ICC for BCRP in untreated (c) and DOX-treated (d) CIPp cell line. ICC for Ki67 in untreated (e) and DOX-treated (f) CIPm cell line. ICC for TERT in untreated $(\mathbf{g})$ and DOX-treated (h) CIPp cell line. ICC for p53 in untreated (i) and DOX-treated (j) CIPp cell line; multinucleated cells, indicated by the black arrow, are shown in (d) and (j) and cells with micronuclei, indicated by black arrowhead, are shown in (j). Figures at 200x magnification

Cells treated with $\mathrm{EC} 0_{(20 \mathrm{~h})}$ of DOX demonstrated an increase in cell size for both cell lines and, for CIPp only, the presence of multinucleated cells, often in association with karyomegaly and multiple micronuclei (Fig. 6(d), (h) and (j)).

\section{MDR direct dye efflux assay}

The MDR Direct Dye Efflux Assay was performed to evaluate the functionality of P-gp and BCRP expressed by CIPp and CIPm. In both CIPp and CIPm the fluorophore efflux was evident at each time point becoming almost complete at $24 \mathrm{~h}$ (Fig. 7). Vinblastine, a well-known substrate for P-gp pumps, exerts a selective competitive inhibitory effect and was used as an internal control. In both CIPp and CIPm, P-gp efflux capacity was dampened by the treatment with Vinblastine at all time points; CIPm were less affected by Vinblastine treatment as evidenced by the difference $(\Delta)$ in MFI between positive control cells and Vinblastine treated ones (P-V), CIPm were able to extrude a larger dye quantity than the CIPp in any case except at $1 \mathrm{~h}$ (Fig. 7). Representative histograms of the MDR Direct Dye Efflux Activity in CIPp and CIPm are displayed in Fig. 7, where a peak shoulder is observed at 24 $\mathrm{h}$ in Vinblastine treated CIPp cells; this peak may be related to the presence of two cell populations, a smaller one rich in channels, able to efflux a quantity of dye similar to positive control cells even in presence of the inhibitory competitor, and a larger cell population in which the efflux is clearly limited by Vinblastine presence (Table 1).

\section{Discussion}

P-gp and BCRP changes at gene expression and cellular phenotype levels after exposure to Doxorubicin

The administration of DOX significantly enhanced the transcription of $P-g p$ and $B C R P$ genes, presumably associated to a functional need of efflux pumps in cells targeted by DOX $[28,36]$. CIPp, the cell line established from the primary CMT, at $48 \mathrm{~h}$ showed increase in the gene expression of both $P-g p$ and $B C R P$. CIPm, cells

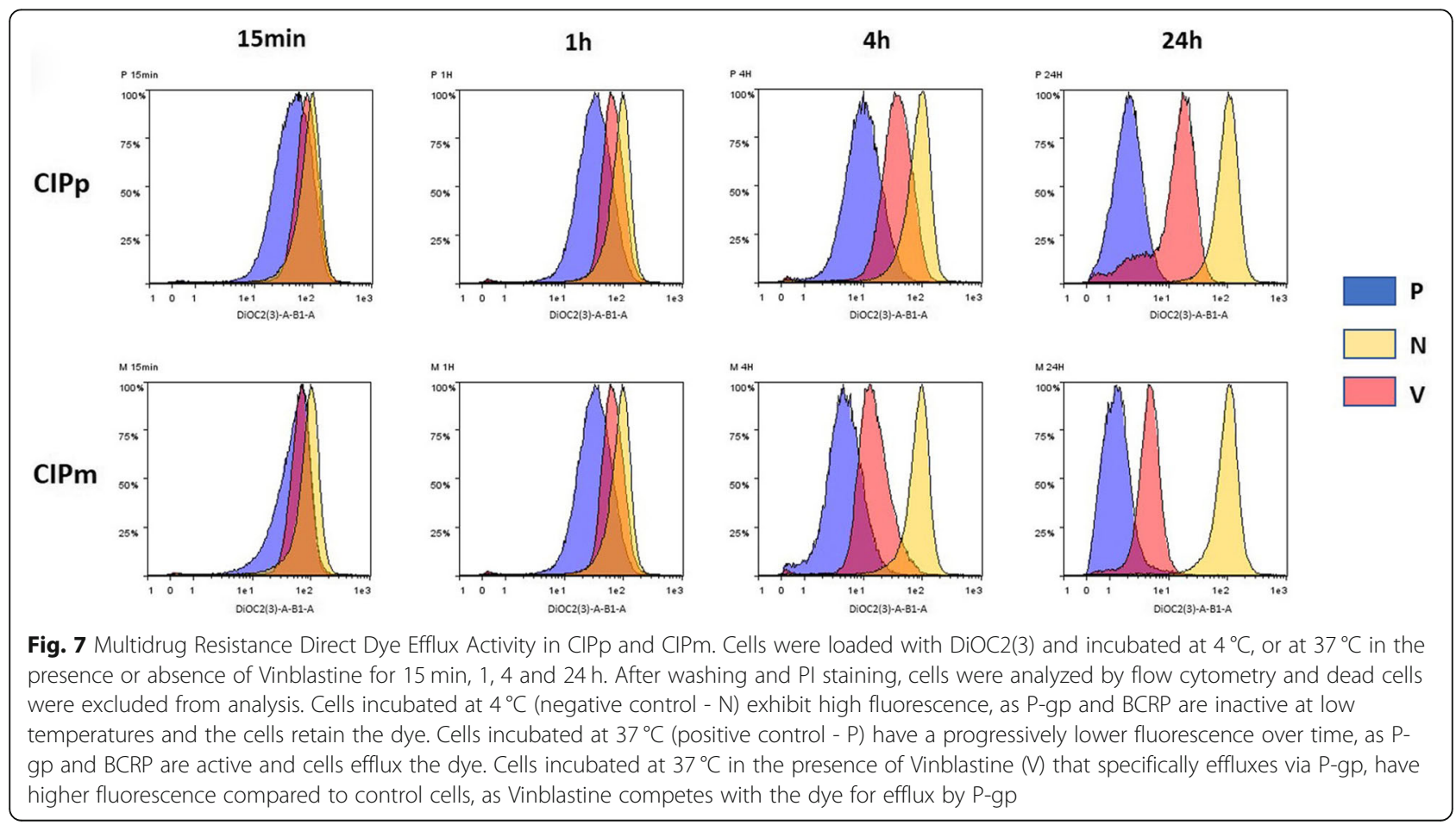


Table 1 Multidrug Resistance Direct Dye Efflux Activity in CIPp and CIPm

\begin{tabular}{|c|c|c|c|c|}
\hline & \multicolumn{2}{|c|}{ CIPp } & \multicolumn{2}{|c|}{ CIPm } \\
\hline & $\Delta(\mathrm{N}-\mathrm{P}) \mathrm{MFI}$ & $\Delta(\mathrm{P}-\mathrm{V}) \mathrm{MFI}$ & $\Delta(\mathrm{N}-\mathrm{P}) \mathrm{MFI}$ & $\Delta(\mathrm{P}-\mathrm{V}) \mathrm{MFI}$ \\
\hline $15 \mathrm{~min}$ & $43.87 \pm 5.74$ & $-33.34 \pm 5.68^{*}$ & $41.55 \pm 5.69$ & $-14.49 \pm 5.38^{*}$ \\
\hline $1 \mathrm{~h}$ & $60.15 \pm 5.81$ & $-34.09 \pm 5.33$ & $59.75 \pm 6.15$ & $-29.15 \pm 6.11$ \\
\hline $4 \mathrm{~h}$ & $81.32 \pm 5.25$ & $-28.25 \pm 6.01^{*}$ & $86.71 \pm 5.13$ & $-9.70 \pm 5.08^{*}$ \\
\hline $24 \mathrm{~h}$ & $101.06 \pm 4.98$ & $-13.58 \pm 5.12^{*}$ & $101.47 \pm 4.85$ & $-3.49 \pm 2.54^{*}$ \\
\hline
\end{tabular}

Differences $(\Delta)$ between median fluorescence intensity (MFI) values: $\Delta \mathrm{N}-\mathrm{P}$ (negative controls at $4{ }^{\circ} \mathrm{C}$ - positive controls at $37^{\circ} \mathrm{C}$ ) represents the amount of fluorescent dye effluxed at each time point, $\Delta \mathrm{P}-\mathrm{V}$ (positive controls at $37^{\circ} \mathrm{C}$ - cells treated with Vinblastine at $37^{\circ} \mathrm{C}$ ) represents the reduction of dye effluxed in presence of Vinblastine in CIPp and CIPm. Asterisk indicates a significative difference between the two cell lines in the same condition (Student's t test $p<0.05$ )

forming the lymph node metastases, showed a greater increase of BCRP than P-gp, compared to controls.

At ICC, the percentage of cells immunolabeled by Pgp and BCRP was highly variable. CIPp manifested an increase in the expression of both the transporters compared to the controls at any time points, whereas in CIPm the percentage of P-gp and BCRP positive cells was higher at $24 \mathrm{~h}$ for BCRP and, at $48 \mathrm{~h}$ of treatment, for P-gp. The difference in the results between ICC and qRT-PCR can be explained by the fact that at early treatment time points (12 and 24h) DOX-sensitive cells died while the cells bearing intrinsic DOX resistance remained viable and could be stained by ICC. Instead, qRT-PCR was able to detect an increase in the mRNA transcript mostly evident at $48 \mathrm{~h}$ when cells subjected to treatment enhance their transcription machine in order to increase their ability to survive DOX treatment. Moreover, qRTPCR is a quantitative method that detects the presence of a specific mRNA over the total mRNA in a cellular population, but it does not allow the detection of cellular diversity in the population; on the other hand ICC highlights single positive cells but not to permit the quantifications of the number of the pumps present in a single cells. The number of P-gp and BCRP positive cells by ICC, is not necessarily related to the amount of gene expression detected by qRT-PCR. The number of cells evaluated by ICC in the chamber slides at $48 \mathrm{~h}$ was extremely reduced by the $\mathrm{EC} 50_{(20 \mathrm{~h})} \mathrm{DOX}$ treatment, hence representing a bias for quantification of the pumps.

Intrinsic expression of P-gp and BCRP was shown in the two cell lines examined in this study. The treatment with DOX demonstrated that cells that were able to survive had a higher expression of both P-gp and BCRP thus they escaped the drug action through MDR related mechanisms [5, 37].

Drug resistance to vinblastine in CMTs cell lines is documented [30] and a high expression of P-gp [29] and BCRP [28] in CMT cell lines led to the conclusion that the use of DOX could lead to chemoresistance in treated bitches [28].

In the present study ICC has been a valuable technique for assessing the subcellular localization of P-gp and BCRP which were identified both at the plasma membrane and in the cytoplasm of the cells, lining cytoplasmic vacuoles. The expression of both ABC-transporters has been documented at membranous level, where they exert their function of efflux pumps, extruding drug from the nucleus and cytoplasm [5, 38, 39], while in the cytoplasmic cellular compartment where they are found on cytoplasmic lysosomal vacuoles, known as drug safe houses, which have the function of segregating the drug preventing its action into the nucleus [10, 11, 40-42].

Another interesting finding at ICC was the presence of a substantial fraction of cells showing karyomegaly, micronuclei and multinucleated cells in treated CIPp especially. This finding can be associated with a DNA damage due to DOX treatment that increases ploidy and severe nuclear anomalies of cancer cells including giant cells, polyploid and polymorphism, comprising multinucleated cells and micronuclei that have been reported as an indicator of genetic instability [43-46].

\section{Effects of Doxorubicin on cell cycle progression and cellular proliferation - Ki67 index, p53 and TERT}

In the present study DOX exposure showed an important effect on both CIPp and CIPm affecting cellular distribution in the cell cycle phases. The cytotoxic action of DOX resulted in cell cycle arrest in S phase for CIPp complemented by cellular death increase. On the contrary, CIPm did not arrest at cellular checkpoints, but the reduction of cellular percentage in G0/G1 went on parallel with cellular death increase. The absence of the arrest at $\mathrm{S}$ phase in CIPm could be interpreted as a loss of the cellular checkpoints associated with the progression of the tumour from primary (CIPp) to metastatic (CIPm). Besides, changes in Ki67 labeling index measured during treatment are reportedly to be a superior predictor of response than similar measurements taken prior to treatment [47]. DOX is known for influencing the cell cycle and proliferative activity with different effect associated to the cell type and dose of DOX itself [48] and can influence the proliferative activity in an heterogeneous way depending on the dose and the cell line as well by different gene expression [49].

The most evident effects of DOX treatment on the cellular phenotype were the striking increase in the percentage of p53 and TERT positive cells for both cell 
lines when treated with DOX $\mathrm{EC} 50_{(20 \mathrm{~h})}$ at all time points. In fact, DOX has multiple mechanism of action involving, in some cases, the activation of p53 [48]. Moreover, the genetic instability, which is the consequence of DOX administration and loss of wild type p53 function, has been suggested as the property which allows highly malignant cells to amplify the $M D R-1$ gene and thus become resistant to a wide spectrum of cytotoxic drugs [50].

Hence, an important information was that in both untreated cell lines p53 is functional/not mutated and that DOX treatment could activate its function. P53 activation conceivably mediated the cell cycle arrest in the $\mathrm{S}$ phase in CIPp and cellular death in CIPm. A functional p53 can represent a protective mechanism in a neoplastic population treated by DOX, in fact the arrest of the cell cycle can lead to p53-mediated activation of reparative processes in neoplastic cells that could therefore survive the treatment and be able to regrow upon chemotherapy withdrawal $[49,51,52]$. P53 function has an important role in chemotherapy efficacy, mediating apoptosis of neoplastic cells targeted by many drugs [53-57].

At $48 \mathrm{~h}$ treatment an increase of the percentage of p53 positive cells is seen in untreated cell lines, probably because of hyper-confluence and deficiency of nutrients of the cell culture [58].

A significant increase in TERT activation and expression, both in nuclei and cytoplasm, is another finding in DOX treated cell lines. These can be explained by an attempt of neoplastic cells to protect themselves from the damage induced by DOX, conferring drug resistance. Telomerase is the ribonucleoprotein responsible for de novo synthesis and maintenance of telomeres, and its activity is predominantly observed in cancer cells $[59,60]$. It is well known that a decreased expression or inhibited activity of telomerase in cancer cells is accompanied by an increased sensitivity to some drugs (e.g., DOX, cisplatin, or 5-fluorouracil) [55], however, the mechanism of the resistance resulting from telomerase alteration remains elusive [59]. Telomerase can translocate from the nucleus into the mitochondria to protect the cells from apoptosis mediated by ROS stress, being ROS production a well-known mechanism of damage from DOX to neoplastic cells $[59,60]$. TERT can prevent cell death by elongating and rebuilding the telomeres and by increasing TERT concentration in the mitochondria preventing apoptosis, influencing therefore the efficacy of the treatment $[54,59,61,62]$. The minimal set of changes necessary to obtain tumorigenic drug-resistant cells was found to be expression of telomerase and inactivation of p53 and pRb [63], thus as the pathways inactivated or activated in malignant neoplasms can also confer the ability to acquire drug resistance as was observed also in our populations of cells.

\section{Internalization and extrusion of Doxorubicin at different timepoints}

The exact mechanism of action of DOX is complex and still unclear. To exert its function, a drug must reach its intracellular target that, in the case of DOX, is primarily the nucleus $[13,15,64]$. After $3 \mathrm{~h}$ of treatment, DOX reached its target in both CIPp and CIPm while at $48 \mathrm{~h}$ treatment the drug was extruded from the few surviving cells. The Multidrug Resistance Direct Dye Efflux Assay showed that P-gp and BCRP channels were active in both cell lines and able to extrude the substrate in $24 \mathrm{~h}$. Overall, CIPm were more efficient at extruding the exogenous compound compared to CIPp. Being CIPm derived from metastatic tumour this finding could be associated to an increased drug resistance capacity of the metastatic cells compared to their primary counterpart, a phenomenon already reported both in vivo and in vitro [65-68]. Since metastasis is the major cause of cancer death, it is important to address the effect of chemotherapy on metastasis by accurately establish the response of a cell population to the drug to be administered to ensure that the desired effect will be observed both in the metastases and primary tumours [44, 48, 68]. Chemotherapy can radically increase the speed of clonal evolution and lead to new malignant and resistant clones that can cause tumour metastasis. Several aspects of metastatic clones are distinct from primary tumour formation and could influence drug development $[69,70]$.

The qRT-PCR and ICC positively correlate with the test evaluating the transporters functionality (i.e. direct fluorescence of DOX). In fact, at $48 \mathrm{~h}$ the cells that survived treatment showed a complete extrusion of DOX, therefore carrying a phenotype particularly rich in P-gp and BCRP canals. The Multidrug Resistance Direct Dye Efflux Assay showed similar functionality of P-gp and BCRP in CIPp and CIPm in basal conditions, while CIPm showed a decreased sensitivity to the competitive inhibition of the Pgp canals by Vinblastine. CIPm, derived from the metastatic carcinoma, has more efficient P-gp canals, or canals of other types (i.e. MRP-1, LRP) compared to the primary tumour. Moreower, the extrusion assay detected a more complex response in CIPp, with the evidence of different sub-populations of neoplastic cells. A fraction of cells in the primary tumour were more effective in extruding Vinblastine and probably constitute the highly efficient population of CIPm, in the metastatic tumour [68, 71, 72].

Severe effect on cell viability were seen at $48 \mathrm{~h}$ DOX treatment, causing fewer cells available for examination, therefore the results related to this time point should be interpreted with caution.

\section{Conclusions}

The present study investigated the relationship between cancer cells chemosensitivity, the neoplastic phenotype and the subcellular distribution of the chemotherapeutic 
drug DOX in two CMT cell lines CIPp, originated from a primary mammary tumour, and CIPm, initiated from the corresponding lymph node metastases. These cell lines were a valuable model to study the effect of chemotherapy treatments and to investigate the mechanisms associated with cell-survival and death in a subpopulation of cells subjected to chemotherapy. Changes in the cell cycle, p53 expression and TERT activation are interlinked with the modulation of P-gp and BCRP drug transporters and are associated to drug resistance. These findings provide valuable information for revealing the correlation between chemoresistance, phenotypic changes and proliferation dynamics in the neoplastic populations that might significantly contribute to reach over the time to neoplastic survival despite chemotherapy.

\section{Methods}

\section{Cell culture}

The canine mammary carcinoma cell lines, CIPp and CIPm, were kindly provided by prof. Takayuki Nakagawa from the University of Veterinary Medicine of Tokyo, Japan [73]. They were both obtained from a tubular carcinoma of a ten-yearsold ShihTzu female dog; CIPp were derived from the primary tumour mass at mammary gland, whereas CIPm from the metastasis of the primary tumor to the regional lymph node. Both the primitive tumour and its metastasis cell lines were first isolated and established by Uyama et al. (2006) [74] showing that both the cells resulted negative for PR and ER receptors and positive for HER2 protein. Cultured CIPp and CIPm cells were maintained in RPMI 1640 with Glutamax medium supplemented with 10\% FBS, $5 \mathrm{mg} / \mathrm{L}$ gentamicin sulphate, $6 \mathrm{mg} / \mathrm{L}$ fungizone (complete medium) and incubated at $37^{\circ} \mathrm{C}$ in a humidified atmosphere of $5 \% \mathrm{CO}_{2}$. Reagents were purchased by Gibco-Life Technologies (Carlsbad CA, USA). Cells were routinely cultured in T25 tissue culture flasks ( $\mathrm{T}$ 25-Falcon, Beckton-Dickinson, Franklin Lakes, NJ, USA). Successive experiments were conducted in 96-well plates (MTT test), 24-well plates (RNA extraction), 8-slide chambers (DOX-associated fluorescence evaluation and immunocytochemistry) and T25 tissue culture flasks (cell cycle analysis and Multidrug Resistance Direct Dye Efflux Assay). Doxorubicin chlorohydrate $(2 \mathrm{mg} / \mathrm{ml})$ was supplied by Teva Pharmaceutical Industries (Petah Tiqwa, Israel).

\section{MTT assay and EC50 determination}

Cells $\left(3 \times 10^{3} /\right.$ well $)$ were plated into 96 -well plates, allowed to attach for $6 \mathrm{~h}$, and treated with $0 \mu \mathrm{M}$ (control), $0.2,0.6,0.8,1,5,10,50,100 \mu \mathrm{M}$ DOX for $20 \mathrm{~h}$ in a humidified $\mathrm{CO}_{2}$ incubator. Drug was dissolved in complete medium. Mitochondrial activity, as index of cell viability, was evaluated by (3-(4,5-dimethylthiazol-2yl)-2,5-diphenyltetrazolium bromide or MTT test (Sigma-Aldrich, St. Louis, MO, USA) following manufacturer's instructions. Briefly, samples were incubated with MTT solution $(0.5 \mathrm{mg} / \mathrm{mL}$ in PBS) for $2 \mathrm{~h}$, formazan crystals were dissolved in $0.1 \mathrm{~mL} /$ well of MTT Solubilization Solution and absorbance spectrophotometrically measured at $570 \mathrm{~nm}$ using the Infinite ${ }^{\circ} \mathrm{F} 50 /$ -Robotic Absorbance microplate readers (Tecan Life Sciences, Männedorf, Switzerland).

\section{Doxorubicin-associated fluorescence evaluation}

Due to its fluorescence properties and the use of a blue fluorescent dye Hoechst33342 labelling the nucleus, the intracellular distribution of DOX could be observed by the fluorescence microscope [75]. Cells $\left(15 \times 10^{3} /\right.$ chamber $)$ were plated in 8-chamber slides with $500 \mu$ of complete medium and allowed to attach for $24 \mathrm{~h}$ in a humidified $\mathrm{CO}_{2}$ incubator. Medium from each chamber was removed and cells treated with $0 \mu \mathrm{M}$ (control) or EC50 (20h) DOX dose: 12.08 and $9.431 \mu \mathrm{M}$ for CIPp and CIPm respectively. After 3 and $48 \mathrm{~h}$ of DOX treatment, medium was withdrawn, and cells were stained for $30 \mathrm{~min}$ a $37^{\circ} \mathrm{C}$ with Hoechst33342 (Miltenyi Biotec) diluted 1:1000 in complete medium. Cells were washed twice with DPBS (Gibco-Life Technologies) then chambers were detached from slides. [Falcon ${ }^{\mathrm{Tm}}$, Thermo Fisher Scientific, Waltham, Massachusetts, USA] Coverslips were mounted with Fluoroshield (Sigma-Aldrich) and images were obtained with an Eclipse E600 epifluorescence microscope (Nikon, Japan) equipped with a digital camera (Nikon, Japan).

\section{Cell cycle analysis by flow cytometry}

CIPp and CIPm were seeded in T25-flask in complete medium and, when confluence reached approximately $70 \%$, cells were treated with EC50 (20h) DOX dose: 12.08 and $9.431 \mu \mathrm{M}$ for CIPp and CIPm respectively for 3, 6, 12 and $20 \mathrm{~h}$ in a humidified $\mathrm{CO}_{2}$ incubator. Untreated cells were employed as controls. At each time point cells were harvested and counted. Aliquots of $1 \times 10^{6}$ cells were washed twice in $5 \mathrm{ml}$ of PBS w/o Ca ${ }^{2+}$ and $\mathrm{Mg}^{2+}$ (GibcoLife Technologies) and fixed overnight in 70\% ice-cold ethanol $(1 \mathrm{ml})$ added drop-by-drop with continuous vortexing. Then, the cells were washed with $10 \mathrm{ml}$ of PBS and cellular pellet was incubated with $1 \mathrm{ml}$ of staining solution containing $50 \mu \mathrm{g} / \mathrm{ml}$ of PI (Miltenyi Biotec, Bergisch Gladbach, Germany) and $100 \mu \mathrm{g} / \mathrm{ml}$ RNaseA/T1 (Thermo Scientific) in PBS for $30 \mathrm{~min}$ in the dark at room temperature (RT). Cell distribution in cell cycle phases was analyzed by MACSQuant ${ }^{\circ}$ Analyzer10 and Flowlogic software (Miltenyi Biotec). Cellular events were discriminated from debris using forward (FSC-A) and side scatter (SSC-A). Doublets have been excluded for analysis by FSC-area and width (FSC-A/FSC-W). Dean-Jett-Fox Univariate Model was used to determine the percentage of the cell population in different phases of the cell cycle [76]. 
RNA extraction and quantitative real time PCR (qRT-PCR) for P-gp and BCRP after treatments with Doxorubicin CIPp and CIPm were seeded in a 24 wells plate $\left(10^{5}\right.$ cells/well) and exposed to DOX EC50 (20h) dose for different time (3, 6, 12, 20 and $48 \mathrm{~h})$.

The total RNA was extracted using the TRI Reagent and the NucleoSpin RNA II kit. At the end of time and treatment, the cells were lysed using TRI Reagent $(1000 \mu \mathrm{l} /$ well $)$ and mixed by vortex $(30 \mathrm{~s})$, then chloroform $(200 \mu \mathrm{l})$ was added to the suspension and mixed well. After incubation at room temperature $(10 \mathrm{~min})$, the samples were centrifuged at $12000 \mathrm{x} \mathrm{g}$ for $10 \mathrm{~min}$ at $+4^{\circ} \mathrm{C}$ and the aqueous phase was recovered. An equal volume (1.1; v.v) of ethanol (70\%) was added and the resulting solution was applied to the NucleoSpin RNA Column. The RNA purification was performed according to the manufacturer's instructions. The extracted RNA was quantified using the DeNovix DS11 Spectrophotometer (DeNovix - Wilmington, DE, USA), and an A260/A280 ratio was used to evaluate RNA extraction quality. Five hundred nanograms of RNA were retrotranscribed to obtain cDNA in a $20 \mu \mathrm{L}$ final volume, using an iScript cDNA synthesis kit. Quantitative PCR was carried out using a CFX96 thermocycler (Bio-Rad Laboratories). A master mix of the following reaction components was prepared in nuclease-free water to the final concentrations indicated: $0.2 \mu \mathrm{M}$ forward primer, $0.2 \mu \mathrm{M}$ reverse primer, and 1X iTaq Universal SYBR Green Supermix. Two microliters of cDNA were added to $18 \mu \mathrm{L}$ of master mix. All samples were analyzed in duplicate. The amplification cycle for the real time PCR reaction is: $3 \mathrm{~min}$ at $95^{\circ} \mathrm{C}$, 40 cycles at $95^{\circ} \mathrm{C}$ for $10 \mathrm{~s}$ and $60^{\circ} \mathrm{C}$ for $30 \mathrm{~s}$, followed by a melting step from $55^{\circ} \mathrm{C}$ going up to $95^{\circ} \mathrm{C}$ at a rate of $0.5^{\circ} \mathrm{C} / 5 \mathrm{~s}$ increment/cycle. The specificity of the amplified PCR products was confirmed by agarose gel electrophoresis and melting curve analysis.

Primers sequences of interested genes (BCRP and P-gp) and reference genes (glyceraldehyde 3-phosphate dehydrogenase, GAPDH; Ribosomal protein L32, Rpl32; Succinate dehydrogenase, $S D H A$ ) are reported in Table 2.
Real-time efficiency for interested genes was preliminarily evaluated by amplification of a standardized amount of cDNA, starting from $150 \mathrm{ng}$ with subsequent 5 dilutions $(75,15,3,0.6$ and $0.12 \mathrm{ng})$ derived from liver sample (positive control) (qPCR efficiency: BCRP 101\%, P-gp 94.7\%, data not shown).

The expression level of the interest gene (GI) was determined using the $2^{-\Delta \Delta \mathrm{Ct}}$ method [78] in which $\Delta \mathrm{Ct}=(\mathrm{Ct}$ interest gene $-\mathrm{Ct}$ mean ref. genes) and $\Delta \Delta \mathrm{Ct}=\Delta \mathrm{Ct}$ DOX group $\Delta \mathrm{Ct}$ Control group.

\section{Antibodies validation by Western Blotting}

Anti-P-gp (clone C494) and anti-BCRP (clone BXP-21) antibodies were employed after their validation on canine tissues by Western Blot. For this purpose, canine liver (positive control) and muscle (negative control) tissue samples were collected, frozen in liquid nitrogen and stored at $-80{ }^{\circ} \mathrm{C}$ until sample processing. Hundred milligrams of tissue were homogenized in $1 \mathrm{ml}$ of SDS buffer (Tris- $\mathrm{HCl}, 62.5 \mathrm{mM}$; pH 6.8; SDS, 2\%; and glycerol, 20\%) supplemented with a protease inhibitor cocktail (SigmaAldrich). Total protein content was determined by Peterson's Modification of Lowry Method using a Protein Assay Kit (Sigma-Aldrich). Ten and $30 \mu \mathrm{g}$ of total proteins were separated on NuPage $4-12 \%$ bis-Tris Gel (Thermo Scientific, Waltham, MA, USA) for $1 \mathrm{~h}$ at 165 $\mathrm{V}$. The proteins were then electrophoretically transferred onto a nitrocellulose membrane by a semi-dry system (Trans Turbo Blot, Bio Rad, Hercules, CA, USA). Nonspecific binding on nitrocellulose membranes was blocked with ECL Blocking Agent (GE Healthcare Life Sciences, Little Chalfont, Buckinghamshire, UK) in TBST20 (Tris Buffered Saline-0.1\% Tween-20) for $1 \mathrm{~h}$ at RT. After blocking treatment, the membranes were incubated overnight at $4{ }^{\circ} \mathrm{C}$ with the primary antibodies anti-P-gp (clone C494, GeneTex, Irvine, CA, USA) and anti-BCRP (clone BXP-21, Merck Millipore, Darmstadt, DE) 1:800 and 1:1000 respectively in Blocking Agent. Anti-Alfa-tubulin antibody (TU-01, Thermo Scientific) was employed to

Table 2 Informations on primer sequences used for qRT-PCR analysis

\begin{tabular}{lllll}
\hline Gene & Sequence (5'-3') & PCR bp & AN & Reference \\
\hline P-gp & For GCTTAACACCCGGCTCACAGAC & 402 & FJ617477.1 & Pawlowski et al., 2013 [30] \\
& Rev TAAGAAGGGGCACCAATAGAAT & & DQ222459.1 & Present study \\
BCRP & For TTAGACTCCAGCACAGCAAATG & 189 & & Zannoni et al., 2020 [77] \\
GAPDH & Rev AACCCACTGACGCAAAGAAC & & NM_001003142 & Zannoni et al., 2020 [77] \\
Rpl32 & For TGTCCCACCCCCAATGTATC & 100 & NM_001252169.1 & Zannoni et al.; 2020 [77] \\
Sdha & Rev CTCCGATGCCTGCTTCACTACCT & & & XM_535807 \\
& For GGCACCAGTCAGACCGATATG & 209 & & \\
\hline
\end{tabular}


reveal this housekeeping protein (1:500 in TBST-T20). After washes, the blot was incubated with an anti-mouse IgG, HRP-linked Antibody (Cell Signaling Technology, Danvers, MA, USA), at 1:10000 dilution in TBS-T20, $1 \mathrm{~h}$ at RT and then with an anti-biotin horseradish peroxidase (HRP)-linked antibody (Cell Signaling Technology), (1:100 dilution, $40 \mathrm{~min}$ at RT).

Immunoreactive bands were visualized using chemiluminescent substrate (Clarity Western ECL Substrate, Bio Rad), according to the manufacturer's instructions. The intensity of the luminescent signal was acquired by Chemidoc Instrument (Bio Rad) and the apparent molecular weight of the resultant bands was analyzed by Quantity One Software (Bio-Rad). Western blot analysis of P-gp and BCRP revealed a single band of expected molecular weights, $\sim 140 \mathrm{kDa}$ and $\sim 75 \mathrm{kDa}$ respectively, in canine liver tissue $(30 \mu \mathrm{g})$ but not in canine muscle tissue.

\section{Cell immunocytochemistry}

Considering the generational time of the two cell lines $(\mathrm{TCIPp}=23 \mathrm{~h}$ and $17 \mathrm{~min} ; \mathrm{TCIPm}=20 \mathrm{~h}$ and $29 \mathrm{~min}$ ), cells $\left(20 \times 10^{3}\right.$ and $15 \times 10^{3} /$ chamber per CIPp and CIPm lines, respectively) were plated in 8-chamber slides (BD Falcon $^{\text {Tw }}$ Chamber Cell Culture Slides; Coring Life Sciences, Bedford, MA, USA) with $500 \mu \mathrm{l}$ of complete medium (Falcon ${ }^{\text {tw }}$, Thermo Fisher Scientific, Waltham, Massachusetts, USA) and allowed to attach for $24 \mathrm{~h}$ in a humidified $\mathrm{CO}_{2}$ incubator.

The complete culture medium was removed. Fresh culture medium was added for the controls, instead culture medium added to DOX at a concentration of $1 \mu \mathrm{M}$ was added for treated chambers. Chamber slides were incubated for $12,24,48 \mathrm{~h}$ at $37^{\circ} \mathrm{C}$ at $5 \% \mathrm{CO}_{2}$ to assess P-gp, BCRP, p53, TERT and Ki67 expression. The control medium was then removed from chambers, then washed in. Cells were fixed for $30 \mathrm{~min}$ in $4 \%$ formic aldehyde buffered at $\mathrm{pH}$ 7.2, followed by 3 washings in PBS.

Chamber slides were subjected to endogenous peroxidases inhibition $\left(\mathrm{H}_{2} \mathrm{O}_{2} \quad 0.3 \%\right.$ in demineralized water for $\left.5 \mathrm{~min}\right)$. Chambers were incubated for $3 \mathrm{~min}$ with a solution of PBS at pH7.2. Each well underwent a 45-min dark preincubation with a serum free blocking solution (Protein block serum free; Agilent Technologies, Santa Clara, CA, USA). Chamber slides were then incubated overnight at $4{ }^{\circ} \mathrm{C}$ with (1) mouse monoclonal anti-P-gp (clone C494, GeneTex, Irvine, CA, USA), diluted $1: 1500$ in $1 \%$ bovine serum albumin (BSA; Sigma-Aldrich) in PBS; with (2) mouse monoclonal anti-BCRP (clone BXP-21, Merck Millipore, Darmstadt, DE), diluted 1:800 in 1\% BSA in PBS; with (3) mouse monoclonal anti-Ki67 (clone Mib1, Dako, Glostrup, DK), diluted 1:600 in 1\% BSA in PBS; with (4) mouse monoclonal anti-p53 (clone Pab 240, BD Pharmingen, San Jose, CA), diluted 1:100 in 1\% BSA in PBS; and with (4) anti-hTERT monoclonal antibody (clone 44F12, Novocastra, Newcastle upon Tyne, UK), diluted 1:50 in 1\% BSA in PBS. Chamber slides were washed and incubated for 30 min with secondary anti-mouse antibody (biotinylated goat anti-mouse immunoglobulins; Dako, Glostrup, DK) diluted 1:200 in 1\% BSA in PBS. Avidin-biotin detector complex (Vectastain ABC kit; Vector Laboratories, Burlingame, CA, USA) was applied for an incubation time of $30 \mathrm{~min}$. Chambers have been removed from the glass base and were then incubated for approximately 4 min with 3, 3'diaminobenzide tetrahydrochloride (DAB chromogen/substrate kit; Diagnostic BioSystem, Pleasanton, CA, USA). Sections were counterstained with Papanicolau's hematoxylin solution for $45 \mathrm{~s}$. After dehydration in alcohol and clarification in Diaphane, slides were mounted. All steps were performed at room temperature and in the dark, except for the primary antibody incubation at $4{ }^{\circ} \mathrm{C}$. Each experiment was performed in triplicate. For each marker negative control were included and run in parallel. Staining evaluation was performed with an optical microscope (Eclipse E600; Nikon, Shinjuku, Japan). The percentage of P-gp, BCRP, p53, TERT and Ki67 immunopositive cells, both for CIPp and CIPm, was calculated using the 'Cell Counter Notice' plug-in of ImageJ (US National Institutes of Health, Maryland, USA, 2018). For each marker and replicate of the experiment, a minimum of 1000 cells were evaluated when possible, images taken at optical microscope were analyzed using the NIS-Elements $\mathrm{F}$ image software (Nikon, Shinjuku, Japan). Cell percentages were averaged over triplicate samples, and the data are expressed as the mean $\pm \mathrm{SD}$.

\section{Multidrug Resistance Direct Dye Efflux Assay}

The MDR Direct Dye Efflux Assay kit (Merck, Kenilworth, NJ, USA) was used to measure P-gp and BCRP activity following manufacturer's instructions. CIPp and CIPm cells, seeded on T25 culture flasks, were detached by trypsinization, counted and 4 aliquots of $1 \times 10^{6}$ cells for each cell lines were prepared. One aliquot for each cell line was employed as blank for flow cytometry analysis. Other cell suspensions were washed in DPBS and loaded with $0.2 \mu \mathrm{g} /$ $\mathrm{ml}$ of 3,3'-Diethyloxacarbocyanine Iodide $\operatorname{DiOC2}(3)$ in Cold Efflux Buffer (RPMI + 2\% BSA) overall named DiOC2(3) Loading Buffer. Specifically, samples were incubated with $1 \mathrm{ml}$ of DiOC2(3) Loading Buffer $/ 1 \times 10^{6}$ cells for $15 \mathrm{~min}$ on ice to minimize efflux activity. After the incubation time, cells were washed twice in Cold Efflux Buffer $\left(2.5 \mathrm{ml}\right.$ of Cold Efflux Buffer $/ 1 \times 10^{6}$ cells). Cell pellets were suspended in $3 \mathrm{ml}$ of 3 different buffers: $37^{\circ} \mathrm{C}$ Warmed Efflux Buffer (positive control - P); $37^{\circ} \mathrm{C}$ Warmed Efflux Buffer with Vinblastine (V); $4{ }^{\circ} \mathrm{C}$ Ice Cold Buffer (negative control - N). DMSO was added as vehicle control. Samples in Warmed Efflux Buffer were incubated at $37^{\circ} \mathrm{C}$ while samples in Ice Cold Buffer were maintained on ice for $15 \mathrm{~min}, 1 \mathrm{~h}, 4 \mathrm{~h}$ and $24 \mathrm{~h}$. At the end of each 
incubation times, cells were washed twice in Cold Efflux Buffer then cell pellets were suspended in $0.5 \mathrm{ml}$ of Cold PI (1:50) Buffer to evaluate cell mortality.

The samples were analysed with the MACSQuant Analyzer 10 (Miltenyi Biotec Bergisch Gladbach, Germany) equipped with three lasers (405, 488 and 638 $\mathrm{nm})$. Data analysis was performed using Flowlogic software (Miltenyi Biotec, Bergisch Gladbach, Germany). Cellular events were discriminated from debris using forward (FSC-A) and side scatter (SSC-A). Doublets have been excluded from analysis by FSC-area and weight while dead cells were eliminated from the analysis basing on PI fluorescence. DiOC2(3) signal (excitation/emission: 482/500) was collected in the B1 channel $(525 / 50 \mathrm{~nm})$. For each analysis we recorded at least 200, 000 events. Median fluorescence intensity (MFI) of each peak were considered so differences $(\Delta)$ between MFI values of sample maintained on ice and sample in warmed buffer $(\Delta \mathrm{N}-\mathrm{P})$ and between sample in warmed buffer and sample added with Vinblastine $(\Delta \mathrm{P}-\mathrm{V})$ were calculated. For spectral compensation, the following samples were utilized: cells not stained (Blank), cells loaded for $15 \mathrm{~min}$ on ice with DiOC2(3) Loading Buffer and cells stained with PI (1:50) in Cold Efflux Buffer. At the end of the incubation time cells were washed and suspended in $250 \mu \mathrm{l}$ of Cold Efflux Buffer. The compensation setting was applied to all analysis.

\section{Statistical analysis}

Statistics were calculated with Prism 7 software (GraphPad San Diego, CA, USA). Graphs were created by the same software.

\section{EC50 determination}

EC50 $(20 \mathrm{~h})$ values were calculated using nonlinear regression curve as previously described [79]. Each treatment was analysed in quadruplicate, and the experiment was repeated three times.

\section{Cell cycle analysis}

Data statistics were performed with Student's t test comparing the percentage of cells in every phase of cell cycle (subG0/G1, G0/G1, S, G2/M) in treated vs control cells at the same time points $(3,6,12$ and $20 \mathrm{~h}) . p<0.05$ was considered significant.

\section{Gene expression}

Data statistics were performed with Student's t test comparing treated vs control at the same time points $(3,6$, 12,20 and $48 \mathrm{~h}$ ). $p<0.05$ was considered significant.

\section{Cell immunocytochemistry}

Data statistics were performed with the two-tail Fisher exact test comparing the percentage of positive cells between controls and DOX treated at each time point (12, 24, 48 h). $p<0.05$ was considered significant.

\section{Multidrug Resistance Direct Dye Efflux Assay}

Data statistics were performed by Student's t test on median fluorescence intensity (MFI) values comparing the two cell lines in the same condition (amount of fluorescent dye effluxed and reduction of dye effluxed in presence of Vinblastine at $15 \mathrm{~min}$ and $1,4,24 \mathrm{~h}$ ). $p<0.05$ was considered significant.

\section{Supplementary Information}

The online version contains supplementary material available at https://doi. org/10.1186/s12917-020-02709-5.

Additional file 1. Cell cycle distribution in CIPp. Grouped histograms graph for CIPp treated with DOX EC50 (20h) for 3, 6, 12 and $20 \mathrm{~h}$ in comparison with the relative CTRs. Cell percentages were averaged over triplicate samples, and the data are expressed as the mean \pm SD. Paired Student's t-test (parametric data), asterisk indicates a significant difference $(p<0.05)$ between controls and treated cells. Sub G0/G1 blue, G0/G1 red, $S$ yellow, G2/M green.

Additional file 2. Cell cycle distribution in CIPm. Grouped histograms graph for CIPm treated with DOX EC50 $(20 \mathrm{~h})$ for 3, 6, 12 and $20 \mathrm{~h}$ in comparison with the relative CTRs. Cell percentages were averaged over triplicate samples, and the data are expressed as the mean \pm SD. Paired Student's t-test (parametric data), asterisk indicates a significant difference $(p<0.05)$ between controls and treated cells. Sub G0/G1 blue, G0/G1 red, S yellow, G2/M green.

Additional file 3. Western Blot for BCRP and P-gp. Canine liver was used as the positive control and canine skeletal muscle as negative control. The a-tubulin was used as a housekeeping protein. (A) Western Blot for BCRP detected a single molecular weight specific band of approximately $75 \mathrm{kDa}$. (B) Western Blot for P-gp detected a single molecular weight specific band of approximately $140 \mathrm{kDa}$. Lane $1=10 \mu \mathrm{g}$ of liver tissue Lane $2=30 \mu \mathrm{g}$ of liver tissue Lane $3=10 \mu \mathrm{g}$ of skeletal muscle tissue Lane $4=30 \mu \mathrm{g}$ of skeletal muscle tissue MWM = Molecular Weight Marker expressed in kDa.

Additional file 4. Immunocytochemistry (ICC) results and statistical comparisons. P-gp, BCRP, p53, TERT expression and the Ki67 proliferation index were evaluated in CIPp and CIPm by ICC at 12, 24, $48 \mathrm{~h}$ of treatment with the $\mathrm{EC} 50_{(20 \mathrm{~h})}$ dose of DOX and compared to the corresponding control cultures.

\section{Abbreviations}

BCRP: Breast Cancer Resistance Protein; CMC: Canine mammary tumour; CTR: Control; DOX: Doxorubicin chlorohydrate; FBS: Foetal bovine serum; EC50(20h): Median effective concentration at $20 \mathrm{~h}$ of DOX treatment; EDTA: Ethylenediaminetetraacetic acid; ICC: Immunocytochemistry; mRNA: Messenger Ribonucleic Acid; MTT: 3-(4,5-dimethylthiazol-2-yl)-2,5diphenyltetrazolium bromide; p53: Tumour protein p53; PI: Propidium iodide; qRT-PCR: Quantitative Real Time Polymerase Chain Reaction; PBS: Phosphatebuffered saline; P-gp: P-glycoprotein; SDS: Sodium dodecyl sulphate;

TERT: Telomerase reverse transcriptase

\section{Acknowledgements}

The authors thank Dr. Chiara Agnoli of the Department of Veterinary Medical Sciences, University of Bologna, who kindly provided the chemotherapeutic drug Doxorubicin chlorohydrate. The authors are grateful to the DIMEVET for the contribution for the purchase of the "MACSQuant Analyzer 10".

\section{Authors' contributions}

GS, MF, ML, RS and RDM, conception and design of the work; GS, MF, ML, $F P, R S, C B e r, A Z, R D M, C G, A M$ and $A B$, acquisition, analysis and interpretation of data. GS, MF, ML, FP, RS, CBer, AZ, LVM, BB and CBen, drafted the work and substantively revised the manuscript. All authors read and approved the final manuscript. 


\section{Funding}

The authors received no financial support for the research, authorship, and/ or publication of this article.

\section{Availability of data and materials}

Elaborated data generated or analyzed during this study are included in this published article and its supplementary information files.

\section{Ethics approval and consent to participate}

Not applicable.

\section{Consent for publication}

Not applicable.

\section{Competing interests}

The authors declare that they have no competing interests.

\section{Author details}

'Department of Veterinary Medical Sciences, University of Bologna, Ozzano dell'Emilia, Italy. ${ }^{2}$ Department of Veterinary Sciences, University of Turin, Grugliasco, Italy.

Received: 19 June 2020 Accepted: 3 December 2020

Published online: 18 January 2021

\section{References}

1. Gillet J-P, Gottesman MM. Mechanisms of multidrug resistance in cancer. In: Zhou J, editor. Multi-drug resistance in cancer. Totowa: Humana Press; 2010. p. 47-76. (Methods in Molecular Biology; vol. 596). Available from: http:// link.springer.com/10.1007/978-1-60761-416-6_4. [cited 2020 Mar 21].

2. Zandvliet $M$, Teske $E$. Mechanisms of drug resistance in veterinary oncology — a review with an emphasis on canine lymphoma. Vet Sci. 2015; 2(3):150-84

3. Eckford PDW, Sharom FJ. ABC efflux pump-based resistance to chemotherapy drugs. Chem Rev. 2009;109(7):2989-3011.

4. Arnason T, Harkness T. Development, maintenance, and reversal of multiple drug resistance: at the crossroads of TFPI1, ABC transporters, and HIF1a. Cancers. 2015;7(4):2063-82

5. Gottesman MM, Fojo T, Bates SE. Multidrug resistance in cancer: role of ATPdependent transporters. Nat Rev Cancer. 2002;2(1):48-58.

6. Kovalev AA, Tsvetaeva DA, Grudinskaja TV. Role of ABC-cassette transporters (MDR1, MRP1, BCRP) in the development of primary and acquired multiple drug resistance in patients with early and metastatic breast cancer. Exp Oncol. 2013;35(4):287-90.

7. Clarke R, Leonessa F, Trock B. Multidrug resistance/P-glycoprotein and breast Cancer: review and meta-analysis. Semin Oncol. 2005;32:9-15.

8. Arancia G, Calcabrini A, Meschini S, Molinari A. Intracellular distribution of anthracyclines in drug resistant cells. Cytotechnology. 1998;27(1-3):95-111.

9. Gameiro M, Silva R, Rocha-Pereira C, Carmo H, Carvalho F, de Lourdes Bastos M, et al. Cellular Models and In Vitro Assays for the Screening of modulators of P-gp, MRP1 and BCRP. Mol Basel Switz. 2017;22(4):600.

10. Seebacher NA, Lane DJR, Jansson PJ, Richardson DR. Glucose modulation induces lysosome formation and increases lysosomotropic drug sequestration via the P-glycoprotein drug transporter. J Biol Chem. 2016; 291(8):3796-820.

11. Seebacher NA, Richardson DR, Jansson PJ. A mechanism for overcoming Pglycoprotein-mediated drug resistance: novel combination therapy that releases stored doxorubicin from lysosomes via lysosomal permeabilization using Dp44mT or DpC. Cell Death Dis. 2016;7(12):e2510.

12. Meredith A-M, Dass CR. Increasing role of the cancer chemotherapeutic doxorubicin in cellular metabolism. J Pharm Pharmacol. 2016;68(6):729-41.

13. Carvalho C, Santos RX, Cardoso S, Correia S, Oliveira PJ, Santos MS, et al. Doxorubicin: the good, the bad and the ugly effect. Curr Med Chem. 2009; 16(25):3267-85.

14. Thorn CF, Oshiro C, Marsh S, Hernandez-Boussard T, McLeod H, Klein TE, et al. Doxorubicin pathways: pharmacodynamics and adverse effects. Pharmacogenet Genomics. 2011 Jul;21(7):440-6.

15. Lal S, Mahajan A, Chen WN, Chowbay B. Pharmacogenetics of target genes across doxorubicin disposition pathway: a review. Curr Drug Metab. 2010; 11(1):115-28.
16. Franco YL, Vaidya TR, Ait-Oudhia S. Anticancer and cardio-protective effects of liposomal doxorubicin in the treatment of breast cancer. Breast Cancer Dove Med Press. 2018;10:131-41.

17. Holliday DL, Speirs V. Choosing the right cell line for breast cancer research. Breast Cancer Res BCR. 2011;13(4):215

18. Zapulli V, Peña L, Rasotto R, Goldschmidt MH, Gama A, Scruggs JL. Surgical Pathology of Tumors of Domestic Animals Volume 2: Mammary Tumors. Davis Thompson Foundation; Gurnee, Illinois. 2019;(2):270.

19. Queiroga FL, Raposo T, Carvalho MI, Prada J, Pires I. Canine mammary tumours as a model to study human breast cancer: most recent findings. In Vivo. 2011;25(3):455-65.

20. Nguyen F, Peña L, Ibisch C, Loussouarn D, Gama A, Rieder N, et al. Canine invasive mammary carcinomas as models of human breast cancer. Part 1: natural history and prognostic factors. Breast Cancer Res Treat. 2018;167(3): $635-48$

21. Abadie J, Nguyen F, Loussouarn D, Peña L, Gama A, Rieder N, et al. Canine invasive mammary carcinomas as models of human breast cancer. Part 2: immunophenotypes and prognostic significance. Breast Cancer Res Treat. 2018;167(2):459-68.

22. Levi M, Brunetti B, Sarli G, Benazzi C. Immunohistochemical expression of Pglycoprotein and breast cancer resistance protein in canine mammary hyperplasia, neoplasia and supporting Stroma. J Comp Pathol. 2016;155(4): 277-85.

23. Levi M, Peña L, Alonso-Díez A, Brunetti B, Muscatello LV, Benazzi C, et al. Pglycoprotein and breast cancer resistance protein in canine inflammatory and noninflammatory grade III mammary carcinomas. Vet Pathol. 2019;56(6): 840-7.

24. Ginn PE. Immunohistochemical detection of P-glycoprotein in formalin-fixed and paraffin-embedded normal and neoplastic canine tissues. Vet Pathol. 1996:33(5):533-41.

25. Petterino C, Rossetti E, Bertoncello D, Martini M, Zappulli V, Bargelloni L, et al. Immunohistochemical detection of P-glycoprotein (clone C494) in canine mammary gland tumours. J Vet Med A Physiol Pathol Clin Med. 2006:53(4):174-8.

26. Kim N-H, Hwang Y-H, Im K-S, Kim J-H, Chon S-K, Kim H-Y, et al. Pglycoprotein expression in canine mammary gland tumours related with myoepithelial cells. Res Vet Sci. 2012;93(3):1346-52.

27. Nowak M, Madej JA, Dziegiel P. Expression of breast cancer resistance protein (BCRP-1) in canine mammary adenocarcinomas and adenomas. Vivo Athens Greece. 2009;23(5):705-9.

28. Honscha KU, Schirmer A, Reischauer A, Schoon H-A, Einspanier A, Gäbel G Expression of $\mathrm{ABC}$-transport proteins in canine mammary cancer: consequences for chemotherapy. Reprod Domest Anim Zuchthyg. 2009; 44(Suppl 2):218-23.

29. Król M, Pawłowski KM, Majchrzak K, Mucha J, Motyl T. Canine mammary carcinoma cell line are resistant to chemosensitizers: verapamil and cyclosporin A. Pol J Vet Sci. 2014:17(1):9-17.

30. Pawłowski KM, Mucha J, Majchrzak K, Motyl T, Król M. Expression and role of PGP, BCRP, MRP1 and MRP3 in multidrug resistance of canine mammary cancer cells. BMC Vet Res. 2013;9:119.

31. Darzynkiewicz Z, Juan G. DNA content measurement for DNA ploidy and cell cycle analysis. Curr Protoc Cytom. 2001;Chapter 7:Unit 7.5. https://doi. org/10.1002/0471142956.cy0705s00. PMID: 18770732

32. Panarese S, Brunetti B, Sarli G. Evaluation of telomerase in canine mammary tissues by immunohistochemical analysis and a polymerase chain reactionbased enzyme-linked immunosorbent assay. J Vet Diagn Investig. 2006; 18(4):362-8

33. Lee CH, Kim WH, Lim JH, Kang MS, Kim DY, Kweon OK. Mutation and overexpression of p53 as a prognostic factor in canine mammary tumors. J Vet Sci. 2004;5(1):63.

34. Keller SM, Schade B, Rickenbacher AB, Brugnera E, Wergin MC, Müller EJ, et al. A comprehensive test system to identify suitable antibodies against p53 for immunohistochemical analysis of canine tissues. J Comp Pathol. 2007:137(1):59-70

35. Löhr CV, Teifke JP, Failing K, Weiss E. Characterization of the proliferation state in canine mammary tumors by the standardized AgNOR method with postfixation and immunohistologic detection of Ki-67 and PCNA. Vet Pathol. 1997:34(3):212-21.

36. Trock BJ, Leonessa F, Clarke R. Multidrug resistance in breast cancer: a metaanalysis of MDR1/gp170 expression and its possible functional significance. J Natl Cancer Inst. 1997:89(13):917-31. 
37. Amawi H, Sim H-M, Tiwari AK, Ambudkar SV, Shukla S. ABC transportermediated multidrug-resistant cancer. Adv Exp Med Biol. 2019;1141:549-80.

38. Glavinas H, Krajcsi P, Cserepes J, Sarkadi B. The role of ABC transporters in drug resistance, metabolism and toxicity. Curr Drug Deliv. 2004;1(1):27-42.

39. Ferreira RJ, dos Santos DJVA, Ferreira M-JU. P-glycoprotein and membrane roles in multidrug resistance. Future Med Chem. 2015;7(7):929-46.

40. Wojtowicz K, Januchowski R, Nowicki M, Zabel M. Inhibition of protein glycosylation reverses the MDR phenotype of cancer cell lines. Biomed Pharmacother. 2015;74:49-56.

41. Krawczenko A, Bielawska-Pohl A, Wojtowicz K, Jura R, Paprocka M, Wojdat E, et al. Expression and activity of multidrug resistance proteins in mature endothelial cells and their precursors: a challenging correlation. PLoS One. 2017;12(2):e0172371.

42. Yamagishi T, Sahni S, Sharp DM, Arvind A, Jansson PJ, Richardson DR. Pglycoprotein mediates drug resistance via a novel mechanism involving Lysosomal sequestration. J Biol Chem. 2013;288(44):31761-71.

43. Mosieniak G, Sliwinska MA, Alster O, Strzeszewska A, Sunderland P, Piechota $M$, et al. Polyploidy formation in doxorubicin-treated cancer cells can favor escape from senescence. Neoplasia N Y N. 2015;17(12):882-93.

44. Savatier J, Rharass T, Canal C, Gbankoto A, Vigo J, Salmon J-M, et al. Adriamycin dose and time effects on cell cycle, cell death, and reactive oxygen species generation in leukaemia cells. Leuk Res. 2012; 36(6):791-8.

45. Sliwinska MA, Mosieniak G, Wolanin K, Babik A, Piwocka K, Magalska A, et al. Induction of senescence with doxorubicin leads to increased genomic instability of HCT116 cells. Mech Ageing Dev. 2009;130(1-2):24-32.

46. Jdey W, Thierry S, Popova T, Stern M-H, Dutreix M. Micronuclei frequency in tumors is a predictive biomarker for genetic instability and sensitivity to the DNA repair inhibitor AsiDNA. Cancer Res. 2017;77(16):4207-16.

47. Dowsett M, Smith IE, Ebbs SR, Dixon JM, Skene A, A'Hern R, et al. Prognostic value of Ki67 expression after short-term presurgical endocrine therapy for primary breast cancer. J Natl Cancer Inst. 2007;99(2):167-70.

48. Lüpertz R, Wätjen W, Kahl R, Chovolou Y. Dose- and time-dependent effects of doxorubicin on cytotoxicity, cell cycle and apoptotic cell death in human colon cancer cells. Toxicology. 2010;271(3):115-21.

49. Hallett RM, Huang C, Motazedian A, der Mauer SA, Pond GR, Hassell JA, et al. Treatment-induced cell cycle kinetics dictate tumor response to chemotherapy. Oncotarget. 2015;6(9):7040-52.

50. Bodey B, Bodey B, Gröger AM, Luck JV, Siegel SE, Taylor CR, et al. Immunocytochemical detection of the p170 multidrug resistance (MDR) and the p53 tumor suppressor gene proteins in human breast cancer cells: clinical and therapeutical significance. Anticancer Res. 1997;17(2B): 1311-8

51. Meek DW. Regulation of the p53 response and its relationship to cancer. Biochem J. 2015;469(3):325-46.

52. Speidel D. The role of DNA damage responses in p53 biology. Arch Toxicol. 2015;89(4):501-17.

53. Berns EM, Foekens JA, Vossen R, Look MP, Devilee P, Henzen-Logmans SC, et al. Complete sequencing of TP53 predicts poor response to systemic therapy of advanced breast cancer. Cancer Res. 2000;60(8):2155-62.

54. Aas T, Børresen A-L, Geisler S, Smith-Sørensen B, Johnsen H, Varhaug JE, et al. Specific P53 mutations are associated with de novo resistance to doxorubicin in breast cancer patients. Nat Med. 1996;2(7):811-4.

55. Geisler S, Børresen-Dale A-L, Johnsen H, Aas T, Geisler J, Akslen LA, et al. TP53 gene mutations predict the response to neoadjuvant treatment with 5-fluorouracil and mitomycin in locally advanced breast cancer. Clin Cancer Res Off J Am Assoc Cancer Res. 2003;9(15):5582-8.

56. Ye S, Shen J, Choy E, Yang C, Mankin H, Hornicek F, et al. p53 overexpression increases chemosensitivity in multidrug resistant osteosarcoma cell lines. Cancer Chemother Pharmacol. 2016;77(2):349-56.

57. Müller M, Schleithoff ES, Stremmel W, Melino G, Krammer PH, Schilling T. One, two, three-p53, p63, p73 and chemosensitivity. Drug Resist Updat. 2006:9(6):288-306.

58. Wright Muelas M, Ortega F, Breitling R, Bendtsen C, Westerhoff HV. Rational cell culture optimization enhances experimental reproducibility in cancer cells. Sci Rep. 2018;8(1):3029.

59. Lipinska N, Romaniuk A, Paszel-Jaworska A, Toton E, Kopczynski P, Rubis B. Telomerase and drug resistance in cancer. Cell Mol Life Sci. 2017;74(22): 4121-32.
60. Masutomi K, Possemato R, Wong JMY, Currier JL, Tothova Z, Manola JB, et al. The telomerase reverse transcriptase regulates chromatin state and DNA damage responses. Proc Natl Acad Sci. 2005;102(23):8222-7.

61. Eskiocak U, Işeri OD, Kars MD, Biçer A, Gunduz U. Effect of doxorubicin on telomerase activity and apoptotic gene expression in doxorubicin-resistant and -sensitive MCF-7 cells: an experimental study. Chemotherapy. 2008; 54(3):209-16

62. Kuranaga N, Shinomiya N, Mochizuki H. Long-term cultivation of colorectal carcinoma cells with anti-cancer drugs induces drug resistance and telomere elongation: an in vitro study. BMC Cancer. 2001;1:10.

63. Yagüe $E$, Arance $A$, Kubitza L, O'Hare $M$, Jat $P$, Ogilvie $C M$, et al. Ability to acquire drug resistance arises early during the tumorigenesis process. Cancer Res. 2007;67(3):1130-7.

64. Rivankar S. An overview of doxorubicin formulations in cancer therapy. J Cancer Res Ther. 2014;10(4):853-8.

65. Bao L, Haque A, Jackson K, Hazari S, Moroz K, Jetly R, et al. Increased expression of P-glycoprotein is associated with doxorubicin chemoresistance in the metastatic 4T1 breast cancer model. Am J Pathol. 2011;178(2):838-52.

66. Chen W-J, Wang H, Tang Y, Liu C-L, Li H-L, Li W-T. Multidrug resistance in breast cancer cells during epithelial-mesenchymal transition is modulated by breast cancer resistant protein. Chin J Cancer. 2010;29(2):151-7.

67. Mitra A, Mishra L, Li S. EMT, CTCS and CSCS in tumor relapse and drugresistance. Oncotarget. 2015:6(13):10697-711.

68. Gonzalez-Angulo AM, Morales-Vasquez F, Hortobagyi GN. Overview of resistance to systemic therapy in patients with breast cancer. Adv Exp Med Biol. 2007;608:1-22.

69. Ibragimova MK, Tsyganov MM, Litviakov NV. Natural and chemotherapyinduced clonal evolution of tumors. Biochem Mosc. 2017;82(4):413-25.

70. Anderson RL, Balasas T, Callaghan J, Coombes RC, Evans J, Hall JA, et al. A framework for the development of effective anti-metastatic agents. Nat Rev Clin Oncol. 2019;16(3):185-204.

71. Rosenbloom DIS, Camara PG, Chu T, Rabadan R. Evolutionary scalpels for dissecting tumor ecosystems. Biochim Biophys Acta. 2017;1867(2):69-83.

72. Chitty JL, Filipe EC, Lucas MC, Herrmann D, Cox TR, Timpson P. Recent advances in understanding the complexities of metastasis. F1000Research. 2018;7 Available from: https://www.ncbi.n/m.nih.gov/pmc/articles/PMC6073 095/. [cited 2020 May 25].

73. Murai K, Nakagawa T, Endo Y, Kamida A, Yoshida K, Mochizuki M, et al. Establishment of a pair of novel cloned tumour cell lines with or without metastatic potential from canine mammary adenocarcinoma. Res Vet Sci. 2012;93(1):468-72

74. Uyama R, Nakagawa T, Hong S-H, Mochizuki M, Nishimura R, Sasaki N. Establishment of four pairs of canine mammary tumour cell lines derived from primary and metastatic origin and their E-cadherin expression. Vet Comp Oncol. 2006;4(2):104-13.

75. Kauffman M, Kauffman M, Zhu H, Jia Z, Li Y. Fluorescence-based assays for measuring doxorubicin in biological systems. React Oxyg Species. 2016; Available from: http://www.aimsci.com/ros/index.php/ros/article/view/65. [cited 2020 Jun 4].

76. Fox MH. A model for the computer analysis of synchronous DNA distributions obtained by flow cytometry. Cytometry. 1980;1(1):71-7.

77. Zannoni A, Pietra M, Gaspardo A, Accorsi PA, Barone M, Turroni S, et al. Non-invasive assessment of fecal stress biomarkers in hunting dogs during exercise and at rest. Front Vet Sci. 2020;7 Available from: https://www. frontiersin.org/articles/10.3389/fvets.2020.00126/full. [cited 2020 May 25].

78. Livak KJ, Schmittgen TD. Analysis of relative gene expression data using real-time quantitative PCR and the 2(-Delta Delta C(T)) method. Methods San Diego Calif. 2001;25(4):402-8.

79. Gatti M, Solari A, Pattarozzi A, Campanella C, Thellung S, Maniscalco L, et al. In vitro and in vivo characterization of stem-like cells from canine osteosarcoma and assessment of drug sensitivity. Exp Cell Res. 2018; 363(1):48-64

\section{Publisher's Note}

Springer Nature remains neutral with regard to jurisdictional claims in published maps and institutional affiliations. 